Deliberationes tudományos folyóirat

14. évfolyam 1. szám 2021/1, 102-119.

Kézirat beérkezése: 2021.04.19.

Kézirat befogadása: 2021.08.16.

DOI: 10.54230/Delib.2021.1.102
Deliberationes Scientific Journal Vol.14; Ed.No. 1/2021, pages: 102-119

Paper submitted: 19 th April 2021

Paper accepted: 16th August 2021

DOI: 10.54230/Delib.2021.1. 102

\title{
EGÉSZSÉGFEJLESZTÉS, TUDATOS TÁPLÁLKOZÁS KIALAKÍTÁSA A MINDENNAPOKBAN A KÖZÉTKEZTETÉSI SZOLGÁLTATÁSON KERESZTÜL
}

\author{
Beke Szilvia \\ Gál Ferenc Egyetem, Egészség- és Szociális Tudományi Kar
}

\begin{abstract}
Absztrakt
A közétkeztetési reform elindítása, immáron lassan egy évtizedes múltra tekint vissza, melynek végeredményeként született meg a 37/2014. (IV. 30.) EMMI rendelet a közétkeztetésre vonatkozó táplálkozás-egészségügyi előírásokról. A rendelet immáron korcsoportosan a Food Based Dietary Guidelines európai ajánlásai alapján alakította át a korábbi Menza körképek során bemutatott korántsem ideális helyzetet. Az egészségtudatos táplálkozás kialakítása érdekében a közétkeztetés, mint lehetőség adott, ehhez azonban meg kell őriznünk az étkezők elégedettségét.

A tanulmányom gyakorlati részében három korcsoportban (óvoda, általános és középiskola) végeztem felmérést saját szerkesztésű kérdőívvel, melynek elsődleges célja volt, hogy felmérje, a gyermekek, illetve szülők milyen mértékben elégedettek a közétkeztetéssel, valamint, hogy táplálkozási szokásaik, és alapanyag-ismeretük menynyiben függ a szolgáltatás igénybevételétől. A kiosztott 300 kérdőívből 256 érkezett vissza értékelhetően. Ezen kívül, a kínálat oldaláról a város közétkeztetését biztosító szolgáltató vezetőjével készítettem félig strukturált interjút. Az adataimat Microsoft Excellel és SPSS programok használatával dolgoztam fel.

Az eredmények közül kiemelném, hogy az elégedettség és a szolgáltatás igénybevételi ideje közötti szignifikáns kapcsolat csak a 2-5 éve és az öt évnél régebben igénybevevők között mutatható ki, ugyanakkor az életkor és az elégedettség között negatív korreláció áll fenn, vagyis minél idősebb a válaszadó, annál elégedetlenebb. Az elégedettség esetében a válaszadók érzékenyen reagálnak a körülményekre, melyek közül a legerőteljesebb kapcsolatot a tálalás minőségével, valamint az ételek hőmérsékletével találtam. Ugyanakkor ezeknél erőteljesebb kapcsolat áll fenn az ételek minősége és ízletessége között.
\end{abstract}

Kulcsszavak: közétkeztetés, gyermekek táplálkozása, egészségtudatos táplálkozás, MENZA reform, elégedettség 


\title{
HEALTH PROMOTION, ESTABLISHING A CONSCIOUS NUTRITION EVERYDAY LIFE THROUGH THE COMMUNITY CATERING SERVICES
}

\author{
Szilvia Beke \\ Faculty of Health and Social Sciences, Gál Ferenc University
}

\begin{abstract}
Launching of the community catering reform with its almost a decade-length history ended up the order of 37/2014 (IV.30.) EMMI, which is about the nutritional and medical regulations of community catering. The order, based on Food Based Dietary Guidelines for different age groups together with European recommendations, has been refashioned the previously not ideal picture demonstrated by school dinners' (MENZA) reviews. In order to develop a health-conscious diet, catering has been provided as an option, but for this we need to maintain the satisfaction of the users.

In the practical part of my study I have done a survey in three age groups (kindergarten, primary and secondary school) by self-made questionnaires whose primary aim was to assess how much children and their parents are satisfied with community catering and how much their nutritional habits and knowledge of raw materials/ingredients depend on their usage of the service. From 300 handed-out questionnaires 256 came back with results. Besides them showing the side of the supply I have made a semi-structural interview with the director of the local community catering company. My data were processed by using Microsoft Excel and SPSS programs.

From the results I would underline there is a significant relation between satisfaction and the length of resourcing the service focusing only those who use the service for at least 2-5 years or more than 5 years. Hence, there is a negative correlation between the age and satisfaction, namely the elder the respondent is, the less satisfied he is. In connection with satisfaction the respondents have given a sensible reaction of the conditions from which the strongest relations I have found were the quality of the serving and the temperature of the meal. At the same time there is a stronger relation between the quality of the meal and its taste.
\end{abstract}

Keywords: community catering, child's nutrition, health conscious nutrition, school dinner (MENZA) reform, satisfaction

\section{BEVEZETÉS}

Napjainkra az elhízás, valamint az ebből eredő krónikus degeneratív megbetegedések aránya hazánkban is aggasztó mértéket ölt.

A legtöbb szokás kialakítása születésünktől kezdődik a családban, melyet későbbiekben a nevelési, oktatási intézményekben szerzett ismeretek, valamint a kortár- 
sak körében tapasztaltak fognak kiegészíteni. A közétkeztetés is egy olyan tapasztalat, mellyel az életünk folyamán szinte hosszabb-rövidebb ideig valamennyien találkoztunk. Felmerül a kérdés, hogy lehet-e ezt a szolgáltatást úgy alakítani, hogy a konkrét táplálkozási igényeken túl a prevencióhoz is hozzájáruljon, segítve ezzel, azt, hogy a felnövekvő generáció tudatosabban figyeljen oda saját és majdani gyermekei táplálkozására. Az elmúlt évtizedekben e szolgáltatás számos kritikát kapott, mind szakmai, mind pedig a szolgáltatást igénylők oldaláról. A 2000-es évek elején elkezdődött folyamatos nyomon követés, majd a 2011-ben Békés megyéből elinduló MintaMenza program és a 37/2014. (IV. 30.) EMMI rendelet, egyaránt azt a törekvést támogatja, hogy gyermekeink számára egy kiegyensúlyozott, a korszerü táplálkozástudományi irányelveket szem előtt tartó szolgáltatás jöjjön létre, mely hosszú távon kiegészíti a helytelen táplálkozásból és életmódból kialakuló megbetegedések megelőzését.

\section{GYERMEKEINK EGÉSZSÉGI ÁLLAPOTÁT MEGHATÁROZÓ TÁPLÁLKOZÁSI ÉS ÉLETMÓDBELI SZOKÁSOK}

Az Egészségügyi Világszervezet (WHO) az elhízást 1997-ben hivatalosan is világjárványnak nyilvánította, mely napjainkban a fejlett, és fejlődő országokat egyaránt érinti (Caballero B, 2007.).

A gyermekek egészségmagatartásának nemzetközi vizsgálata - Health Behaviour in School-aged Children (HBSC), négyévente monitorozza az elhízás alakulását, a fizikai aktivitást, az egészségmagatartást, valamint az ehhez társuló szocioökonómia jellemzőket és felmerülő egyenlőtlenségeket - hazánk tekintetében a 2014-es adatokkal összehasonlítva az alábbi tényekre mutatott rá:

- jóval kevesebben reggeliznek rendszeresen és ezzel együtt jelentősen csökkent a gyümölcsöt és zöldséget naponta fogyasztók aránya is, különösen a fiatalabb korcsoportokban. Ugyanakkor csökkent az édesség- és az üdítőital-fogyasztás gyakorisága is;

- a vizsgált korcsoportok közül emelkedett a túlsúllyal, illetve elhízással küzdő gyermeke aránya a 13 éves korcsoportban, míg a többi korcsoport változatlan vagy minimális javulást mutat;

- a legtöbb serdülő étrendje nincs összhangban a táplálkozási ajánlásokkal, ami aláássa az egészséges fejlődés lehetőségét. Három serdülőből körülbelül kettő nem eszik elegendő tápanyagban gazdag ételt, valamint négyből egy minden nap fogyaszt édességet, és hatból egy minden nap iszik cukros üdítőitalt;

- csökkent az alkoholt kipróbálók és a részegség előfordulásának aránya (ELTE Pszichológiai és Pedagógiai Kar, 2021).

A Magyar Dietetikusok Országos Szövetsége, valamint a Nestlé Hungária Kft. együttműködésének köszönhető vizsgálat, melyben 860 gyermek vett részt azzal a céllal, hogy 4-10 éves gyermekek antropometriai adatait, táplálkozásának és fizikai aktivitásának mértékét felmérjék, az alábbi megállapításokat tette: 
- a vizsgálatban részt vevő gyermekek $21 \%$-a túlsúlyos vagy elhízott, iskolás fiúknál mindez a $28 \%$-os értékkel erőteljesebbnek bizonyult.

- A makrotápanyagok összetételét vizsgálva a zsírenergia \%-a mindkét korcsoportban körülbelül 10\%-kal az ajánlott maximum (30\%) felett volt.

- Az $\omega$-6 és $\omega-3$ zsírsav arány a felnőtt lakossághoz hasonló kedvezőtlen arányt mutatott (1:23).

- A napi koleszterin bevitel is lényegesen a napi ajánlott mennyiség feletti értéket mutatott.

- A tápanyag-profil vizsgálat kimutatta, hogy a telített zsírsavak bevitelét az alábbi élelmiszerek adták (a felsorolás csökkenő sorrendben történt): a tej és tejtermékek, a zsiradékok, illetve a húsok és húskészítmények.

- A szénhidrátból származó energia közel 57\%, ugyanakkor a hozzáadott cukorból származó energia jelentősen meghaladja az ajánlott 10\%-ot.

- Az élelmirost fogyasztás, a felmérésben részt vevők $25 \%$-ánál a kritikus érték alatt van.

- A mikrotápanyagok tekintetében a legnagyobb problémát a jelentős nátriumfelvétel és az alacsony kalcium bevitel jelenti, utóbbi a gyermekek mintegy 35\%-át érintette jelen felmérésben.

- A vitaminbevitel is sok esetben jelentősen elmarad a kívánalmaktól, a vizsgált gyermekcsoportok gyakorlatilag $98-100 \%$-a esetén határérték alatti, a táplálékkal fogyasztott D-vitamin felvétele (Schreiberné Molnár, és mtsai., 2017).

Amennyiben a táplálkozáshoz társuló fizikai aktivitást nézzük, akár az iskolában akár a szabadidőben megállapítható -, hogy az a mindennapos testnevelés bevezetése ellenére, elmarad a kívánatos mértéktől. A NETFIT teszt, melyet a 2014/2015. tanévtől minden magyar köznevelési intézmény 5. évfolyamától alkalmaznak, rávilágít arra a tényre, hogy a gyermekek állóképessége, fittsége nem felel meg az elvárásoknak, valamint, hogy a 11-18 éves korosztály napi 2 óránál többet tölt számítógépezéssel vagy mobilozással, illetve hétközben a gyerekek $20 \%$-a, hétvégén pedig $40 \%$-a 2 óránál többet ül a televízió előtt (Kai, 2018).

Az elmúlt egy év pandémiája alatt még tovább romlottak, mind a táplálkozás, mind a fizikai aktivitás területén a gyermekek mutatói. A táplálkozás esetében a GYERE program vizsgálata során, mely 387 gyermeket érintett, kiderült, hogy a digitális oktatás idején a gyermekek 39,8\%-a evett többet, mint egyébként szokott. A bezártság következtében többet nassoltak, s mintegy 44\%-a hízott ezen időszak alatt (Kubányi \& Szücs, 2020).

A táplálkozás és a fizikai aktivitás terén is az egyik legnagyobb gondot a tudatos napirendtervezés okozta. Az online digitális oktatás következtében igen alacsony volt azon gyermekek aránya, akiknél a nagy intenzitású testmozgás elérte a napi kívánatos 60 percet (lányok 16,3\%, fiúk 23,8\%), ezzel párhuzamosan nőtt a képernyő előtt töltött idő, hétköznapokon átlagosan 3,7 óra, míg hétvégén 3,5 óra. Azok a tanulók, akik a digitális oktatás során hétköznaponként tudatos napirendet követtek, kétszer 
annyian érték el az ajánlott testmozgást (31,3\% vs. 14,7\%), illetve kevesebb időt töltöttek képernyő előtt, mint azok, akiknél nem volt napi rutin (Kovács, Kaj, Király, \& Csányi, 2020).

Látva a felnövekvő generáció életmódbeli problémáit, a közétkezés is egy lehetőséget az arra, hogy a prevenció lehetőségével éljünk, mivel minden gyermek hosszabbrövidebb ideig kapcsolatba kerül a szolgáltatással.

\section{KÖZÉTKEZTETÉS FOGALMA ÉS FELADATKÖRE}

A konkrét megfogalmazás a 37/2014 (IV. 30.) EMMI rendelet fogalomtárában olvasható, mely az alábbiak szerint fogalmaz:

„14.4 közétkeztetés: olyan rendszeres étkezést biztosító, szervezett közösségi ellátás, melyet nevelési-oktatási intézményekben, állami és önkormányzati finanszírozású nyári táborokban, fekvőbeteg-szakellátást nyújtó intézményekben, szociális ellátás, gyermekjóléti alapellátás és gyermekvédelmi szakellátás keretében ellátott, különböző korú és egészségi állapotú személyek részére, többnyire előre megrendelés alapján a nap egy meghatározott időszakában, meghatározott időtartamban nyújtanak;" (37/2014. (IV. 30.) EMMI rendelet a közétkeztetésre vonatkozó táplálkozásegészségügyi elöírásokról, 2014)

A rendelet megfogalmazásakor a jogalkotó elsődleges céljai között szerepelt a gyermekek étkeztetésének megreformálása, mindezzel egy olyan hosszútávú folyamat elindítása, mely hozzájárul a jelenlegi kedvezőtlen egészségmutatók pozitív irányba történő elmozdulásához.

A rendelet bevezetését követően szülői oldalról a kritikák, míg a szakemberek részéről a változtatás szükségessége került kihangsúlyozásra. A legutóbbi MENZA felmérés során már számos pozitív változást rögzítettek, így:

- Az egészséges táplálkozáshoz illeszkedő új ételeket vezettek be, új nyersanyagok jelentek meg.

- Növekedett azon iskolák száma, ahol tudják a diétás étkezést biztosítani.

- Csökkent a hagyományos bő zsiradékban történő sütés alkalmazása.

- Növekedett azon iskolák aránya, akik naponta egyszer vagy többször biztosítanak friss zöldséget, illetve gyümölcsöt a gyerekeknek.

- Nőtt azon iskolák aránya, akik részt vesznek az EU-s iskolatej vagy iskolagyümölcs programban.

- Csökkenést mutatott az elörecsomagolt édességeket, nápolyikat árusító iskolai büfék aránya is.

Ugyanakkor számos rendeleti előírás kihívást jelentett, így:

- a naponta biztosítandó teljes kiőrlésü termékek,

- zöldségek, gyümölcsök szerepeltetése az étkezésben,

- olajos magvak megfelelő gyakorisággal történő szerepeltetése,

- az étkezésre biztosított idő tekintetében sem történt jelentős elörelépés,

- több esetben a megfelelő higiéniai lehetőségek sem biztosítottak, 
- a megfelelő folyadékfogyasztás érdekében nem mindenhol biztosított a szabadon fogyasztható víz (Bakacs, Kaposvári, Nagy, Varga, \& Zentai, 2018).

Minden szolgáltatás kapcsán a keresleten és kínálaton túl, rendkívül fontos a vevö elégedettsége, hiszen hosszú távon csak akkor lehet megőrizni a szolgáltatás iránti igényt, ha azzal az igénybevevő elégedett, ezen alapigazság a közétkeztetés területén sem elhanyagolható, hiszen sokszor találkozunk azzal a ténnyel, hogy a gyermek felső tagozatos, illetve középiskolás korban már nem veszi igénybe az étkezési lehetőséget.

A HUNGAST 2015-ös felmérése, mind az ételek változatosságáról, mind a legkedveltebb ételekről képet kap, vizsgálatába 263 intézményvezetőt vont be.

Vizsgálatuk során kiemelten kezelték az alábbi területeket:

- ételek változatossága

- tálalási hőmérséklet

- tálalás módja

- személyzet viselkedése

- étkező kialakítása

- étkezésre biztosított idő

- szolgáltatás ár-érték aránya

- legkedveltebb ételek

- étlap információ tartalma

A szolgáltató az alábbiakban összegezte az eredményeket:

„Nagymértékben befolyásolja még a szolgáltatás megítélését az ételek tálalásának módja, illetve a választási lehetőség biztosítása. Jövőbeni fejlesztéseinket az ételeink íz világának és beltartalmi értékeinek megtartása mellett ennek irányában igyekszünk megvalósítani” (Hungast, 2015).

A szolgáltatókon túl a terület szakemberei is folyamatosan vizsgálják az elégedettséget, hiszen nem mindegy, hogy a szülő milyen ismeretekkel rendelkezik a gyermeke étkeztetéséről, egyáltalán figyeli-e, hogy mit eszik, vagy csak a gyermeke kritikája a meghatározó (Molnár, és mtsai., 2019).

\section{KuTATÁs MÓDSZERE}

A kutatás alap célkitüzése volt, hogy egy kisváros mintáján keresztül betekintést nyújtson a gyermek közétkeztetés aktuális kérdéseibe és felhívja a figyelmet az egészségtudatos táplálkozás kialakításának egy további lehetőségére. Az adatgyüjtést kvantitatív módszer alkalmazása jellemezte, mely során a kérdőív három korcsoportban került kiosztásra: óvodai közétkeztetés esetében, a szülőknek, míg az általános iskolai és középiskolai elégedettség felmérés esetében a tanulóknak. Valamennyi érintett csoport esetében 100-100 darab kérdőív kiosztására került sor. A kérdőívet kitöltők valamennyien ugyanattól a közétkeztetési szolgáltatótól veszik, vagy vették igénybe a szolgáltatást.

$\mathrm{Az}$ értékelhető kérdőívek száma korcsoportonként: 
- óvodai csoport, szülöi kérdőívek száma: $75 \mathrm{db}$

- általános iskolai csoport tanulói kérdőívek száma: $92 \mathrm{db}$

- középiskolai csoport tanulói kérdöívek száma: $86 \mathrm{db}$

A nyert adatok feldolgozása során leíró, valamint matematikai statisztikai módszerek alkalmazására került sor (ANOVA, khí-négyzet, Chronbach alfa, szignifikánsnak abban az esetben tekintettem, ha p<0,05), melynek elkészítése Microsoft Excel, valamint az IBM SPSS 25 szoftver segítségével történt.

\section{EREDMÉNYEK}

1. ábra: Közétkeztetési szolgáltatást igénybevevők százalékos megoszlása a válaszadók között nevelési, oktatási intézménytípusonként $n_{o}=75, n_{a}=92 n_{k}=86$

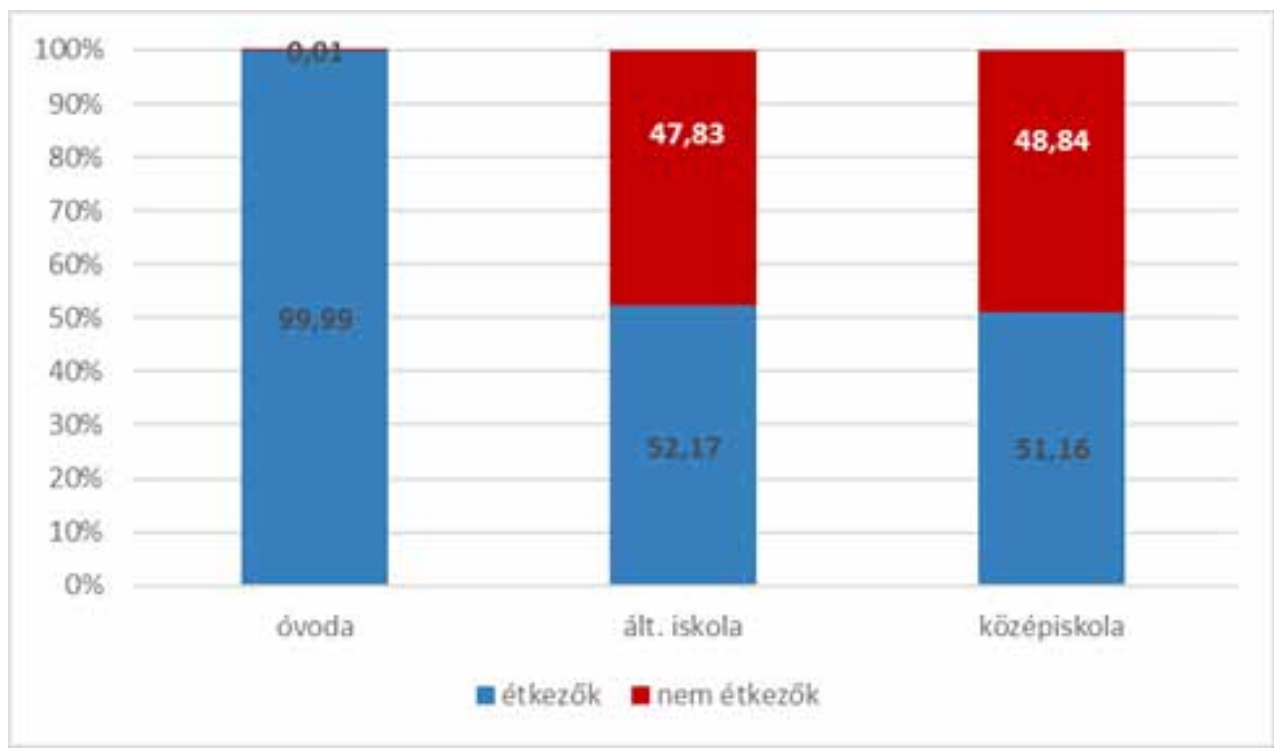

Forrás: saját szerkesztés

A szolgáltatás igénybevétele az óvoda esetében szinte 100\%-os, mindössze egy szülö jelezte, hogy gyermeke nem étkezik az óvodában, mert fött ételt nem fogad el senkitől. A másik két oktatási intézmény esetében ez az arány közel 50-50\%-os, de amint azt a 2 . ábra is mutatja a jelenleg nem étkezők közül is korábban szinte valamennyien étkeztek. 
2. ábra: A „nem étkezők” közül a szolgáltatást korábban

igénybevevők százalékos aránya $n_{a}^{n e ́}=44, n_{k}{ }^{n e}=42$

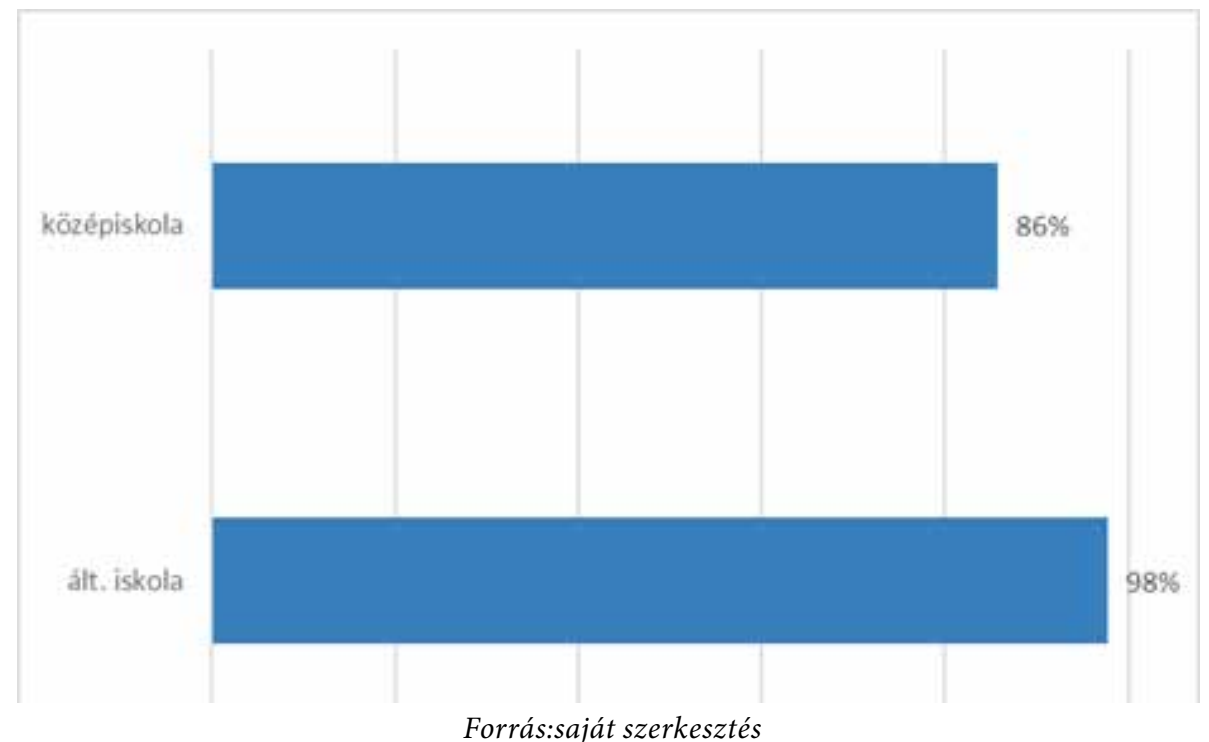

Mindkét esetben a korábban étkezők aránya jelentős mértékű volt, arra a kérdésre, hogy miért döntöttek úgy, hogy nem élnek tovább ezzel a lehetöséggel, kiemelkedő többséggel az „ízetlen volt” indokot választották. Az étkezés során kapott zöldség ételeket, illetve az esetleges anyagi indokot a válaszadóknak csak 18\%-a válaszolta, míg középiskolások esetében még a kortárshatás érvényesülése látható.

3. ábra: Az étkezések számának alakulása a közétkeztetési szolgáltatás igénybevétele alapján $n_{o}=75, n_{a}=92, n_{k}=86$

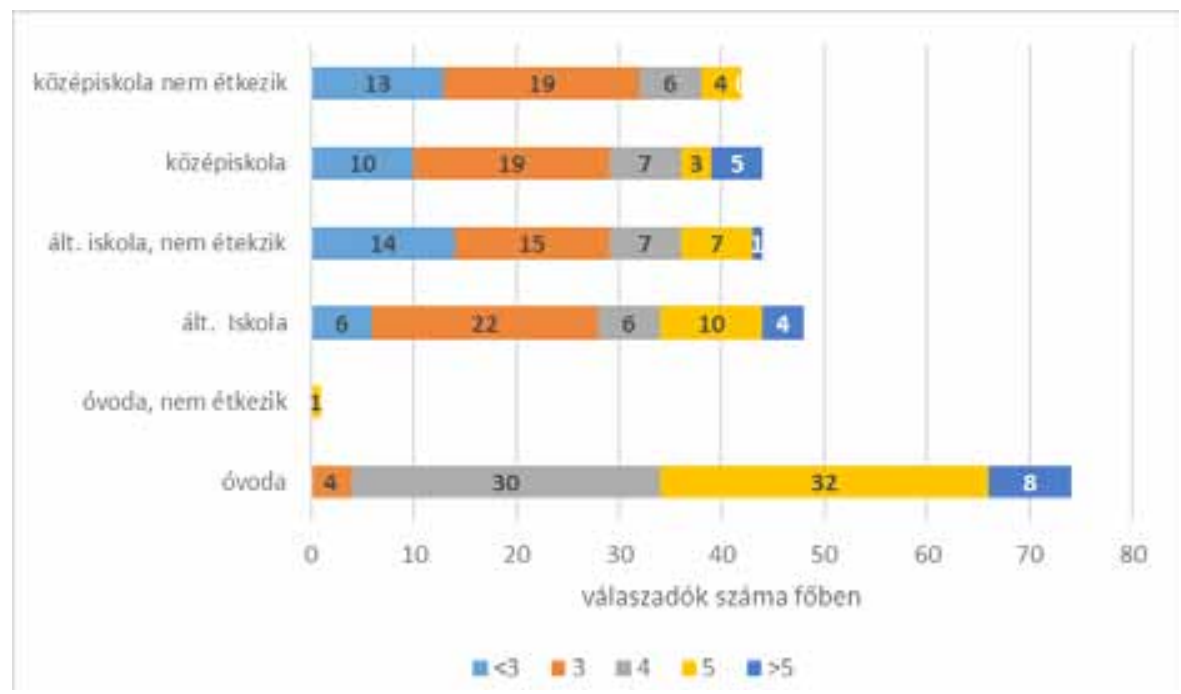

Forrás:saját szerkesztés 
A hétköznapi étkezés esetében ki kell emelni, hogy az egészséges táplálkozás elveit szem előtt tartó napi ötszöri étkezés leginkább az óvodások esetében jellemző, ugyanakkor már ennél a korosztálynál is nyomon követhető, hogy sokan csak napi négy alkalommal esznek, ami leginkább a reggeli elmaradását jelenti, így az első étkezés az óvodában elfogyasztott tízórai. Az általános és középiskolai korcsoport esetében megjelenik a háromszori étkezésnél kevesebb étkezés - mely már a megfelelő tanulást és fejlődést is jelentős mértékben befolyásolja - ezzel együtt a napi ötszöri étkezés általános iskolásoknál a válaszadók alig több, mint 25\%-át, míg a középiskolások 10\%-át érinti.

\section{4. ábra: Az étkezések számának alakulása hétvégén a szolgáltatás} igénybevétele alapján $n_{\dot{o}}=75, n_{\dot{a}}=92, n_{k}=86$

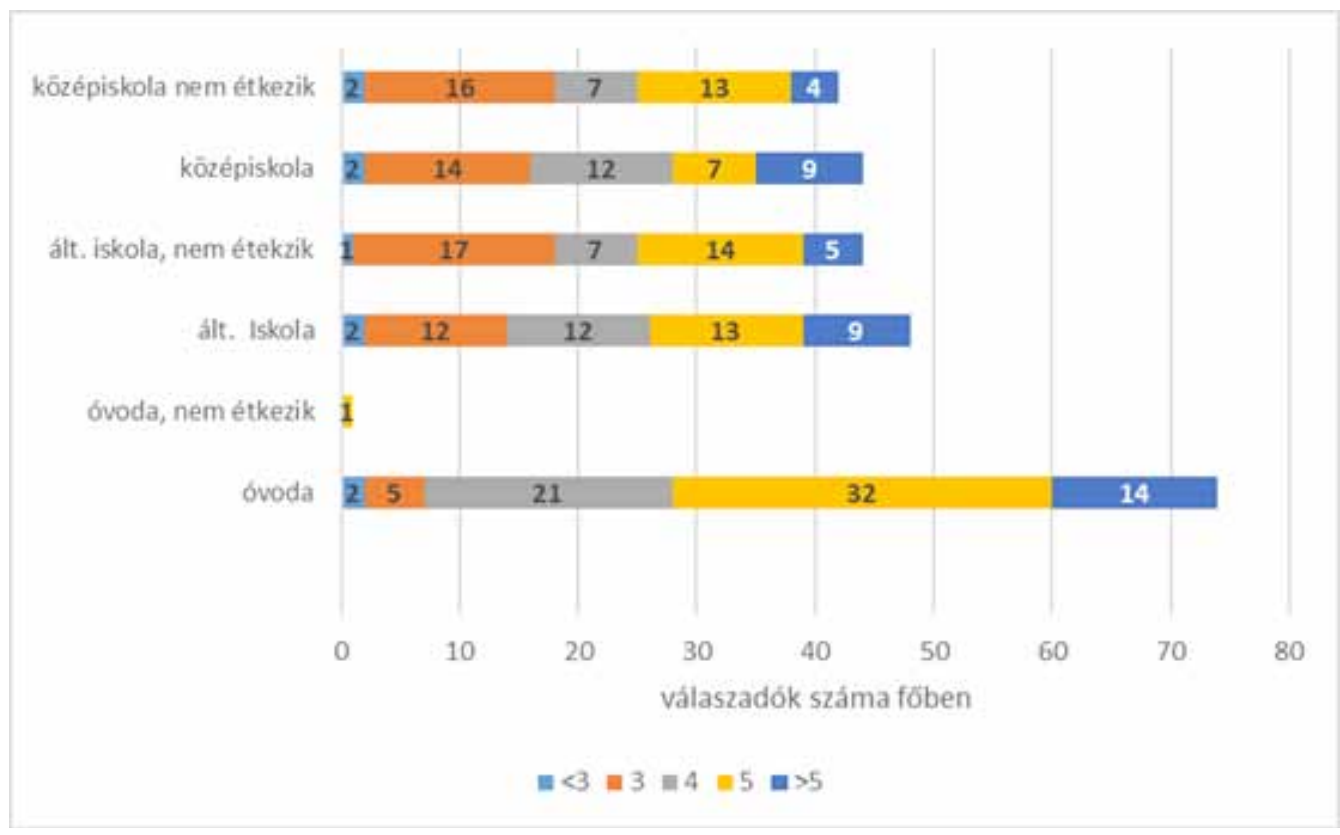

Forrás: saját szerkesztés

Az étkezések számának hétvégi alakulása esetében óvodásoknál az alacsonyabb étkezési szám is megjelenik, ugyanakkor az ötszöri étkezést folytatók száma nem változott, az általános iskolások és középiskolások esetében az ötszöri étkezés emelkedett, ugyanakkor ez nem mutat különbséget a szolgáltatást igénylők és azt mellőzők között.

Az elégedettség mérésének megfelelő kivitelezése érdekében a kérdőív Likert-skálás 13 tényezőt tartalmazó kérdése esetében meghatározásra került a Chronbach alfa, melynek értéke: 0,863 , ez alapján elmondható, hogy jelen tényezők alkalmasak skála létrehozására.

A tizenhárom tényező összegzésével létrehozott skála esetében az értékelési intervallum ennek megfelelően 13-65 érték közé esik (5. ábra). 
5. ábra: A közétkeztetéssel való átlagos elégedettség a szolgáltatás igénybevételi idejének függvényében $n 1=18, n 2=42, n 3=48$

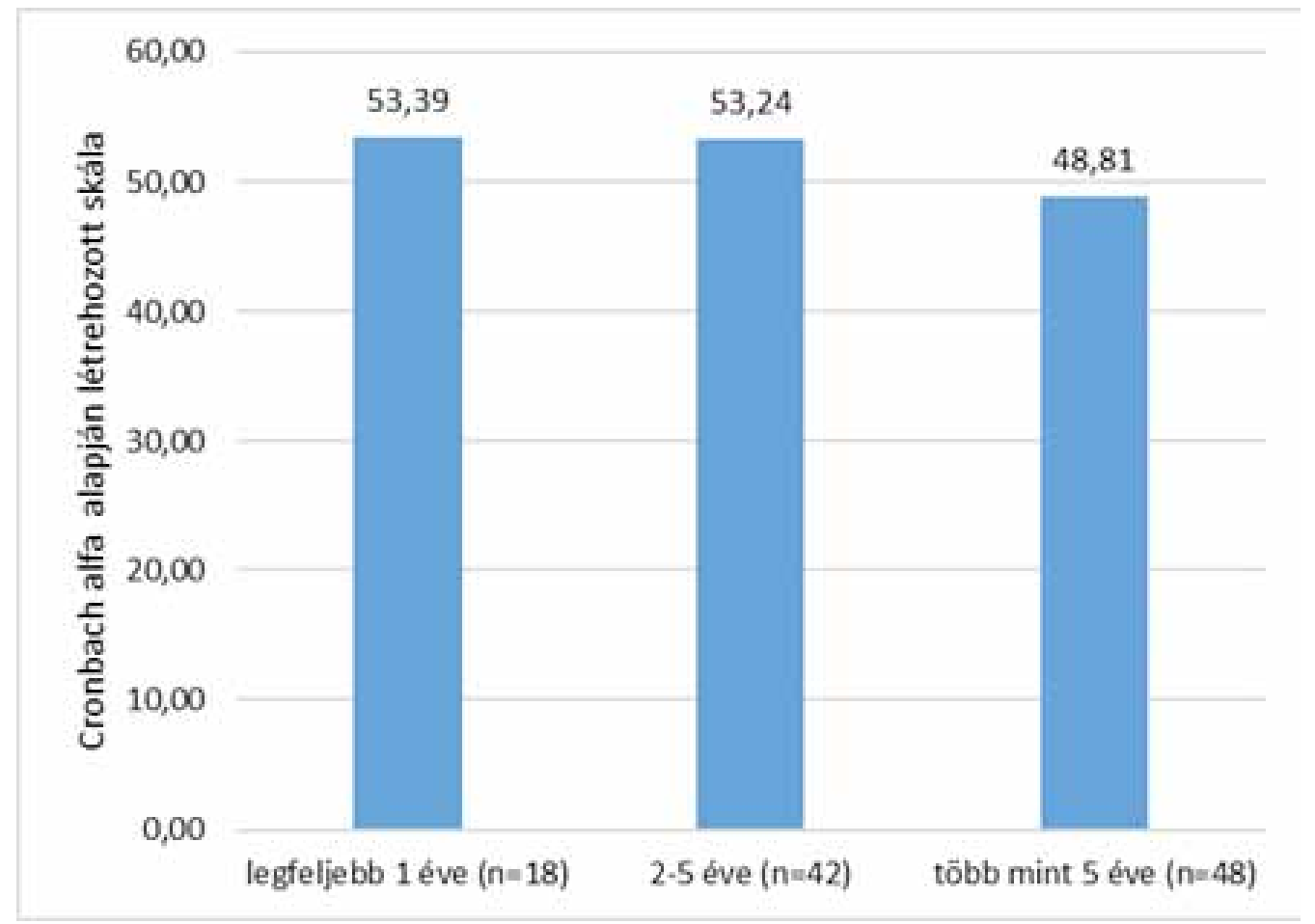

Forrás: saját szerkesztés

Mind a 5. ábra, mind az ANOVA modell, elemzése alapján elmondható, hogy a három csoport átlaga között szignifikáns eltérés nincs $\mathrm{p}=0,057$, de az LSD post hoc teszt alapján a 2. és 3. csoport közötti eltérés szignifikáns $\mathrm{p}<0,05(\mathrm{p}=0,03)$. Amennyiben az életkor és a közétkeztetési szolgáltatás közötti kapcsolatot vizsgáltam, akkor szignifikánsan negatív korrelációs értéket kaptam $\mathrm{R}=-0,377, \mathrm{p}<0,001$, mely arra a tényre világít rá, hogy minél idősebb korcsoporthoz tartozik a válaszadó, annál alacsonyabb az elégedettségi szintje.

Az elégedettség mértékének mérésére szolgált a kérdőív azon kérdése is, hogy a válaszadó 1-től 5-ig (elégtelentől-jelesig) terjedő osztályzattal értékelje a szolgáltatót (6. ábra). 
6. ábra: Az osztályzatok átlag értéke a közétkeztetési szolgáltatásra annak, igénybevételi ideje függvényében (1-5) $n_{1}=29, n_{2}=79, n_{3}=56$

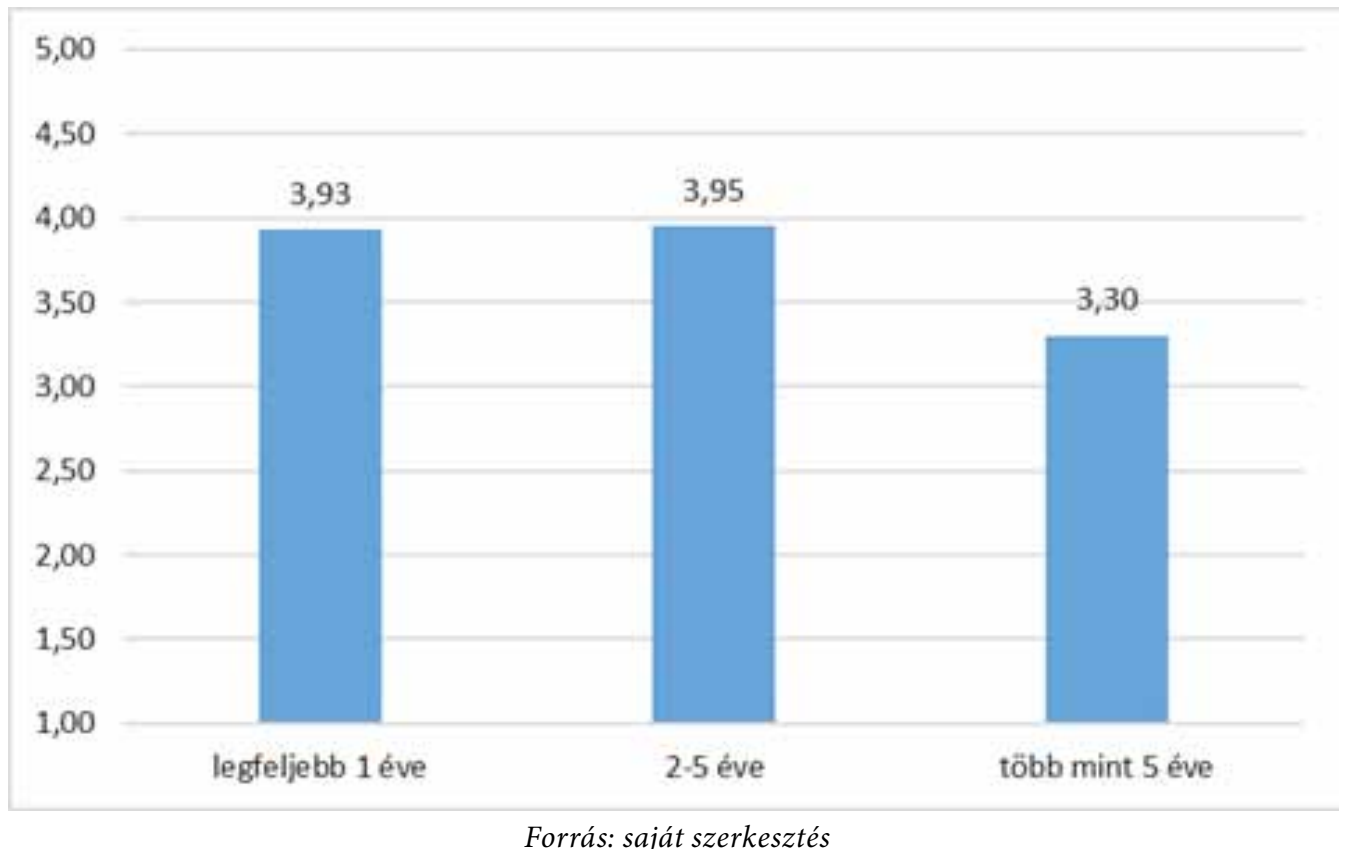

Az ANOVA modell szignifikáns különbséget mutatott a három csoport esetében $\mathrm{p}<0,001$, az LSD post hoc teszt alapján megállapítható, hogy az 1 . és 3 . csoport $(\mathrm{p}=0,003)$ és a 2 . és 3 . csoport $(\mathrm{p}<0,001)$ közötti eltérés szignifikáns. Ugyanezen tényezőnek megvizsgálva az életkorral történő kapcsolatát elmondható, hogy szignifikánsan negatív korreláció $\mathrm{R}=-0,567, \mathrm{p}<0,001$ jellemző.

Az ételek minőségén, változatosságán túl nagyon fontos tényező az, hogy milyen körülmények között fogyaszthatják el mindezt a gyermekek. A korábban már elégedettségi szempontoknál figyelembe vett tényezők és az osztályzatok korrelációja szignifikáns kapcsolatot mutatott az étkezés körülményeivel (7. ábra). 
7. ábra: Az étkeztetés értékelési szempontjainak korrelációja a közétkeztetésre adott osztályzattal (kék-ételek minőségi tényezői, narancssárga-étkezési körülmény) $n_{a+k}=103$

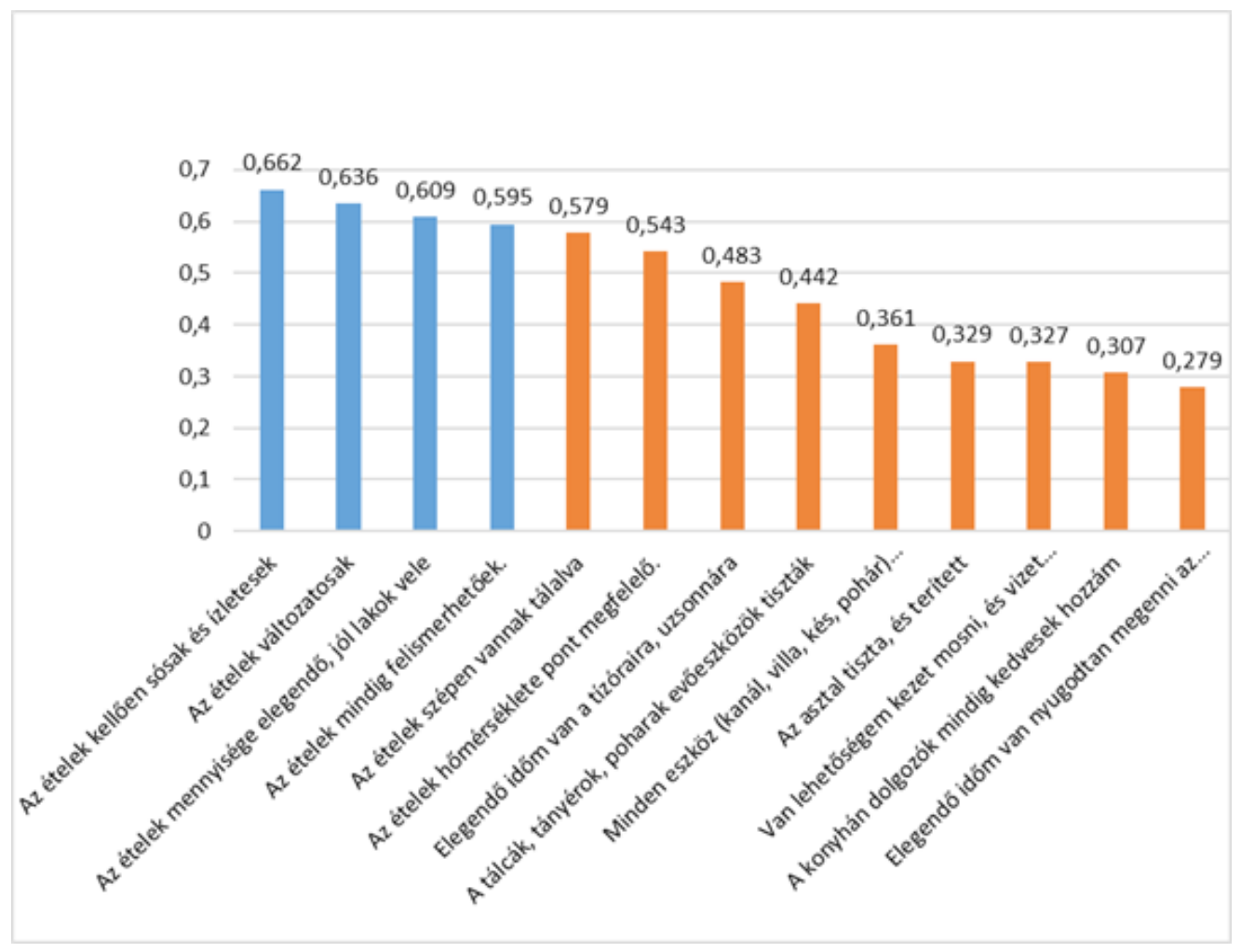

Forrás: saját szerkesztés

Ugyan tény, hogy a legerősebb korreláció az ételek ízletességével és annak minőségével, mennyiségével van, de emellett valamennyi egyéb az étkezés körülményeit meghatározó tényezővel is korrelál és az elégedettséget pozitív vagy negatív irányba mozdítja el.

Általánosés középiskolások esetében a válaszadók feladata volt, hogy az elfogyasztott ételeket egy háromkategóriás skála alapján egy héten keresztül értékeljék, (ízlett, elmegy, nem ízlett).

Ábrázolás tekintetében csak az „ízlett” kategória került kiemelésre, az iskolában elfogyasztott három étkezésre, valamint külön az ebéd fogásaira bontva (8.,9. ábra). 
8. ábra: «Ízlett válaszok aránya az egyes étkezések esetén $n_{a+k}=197$

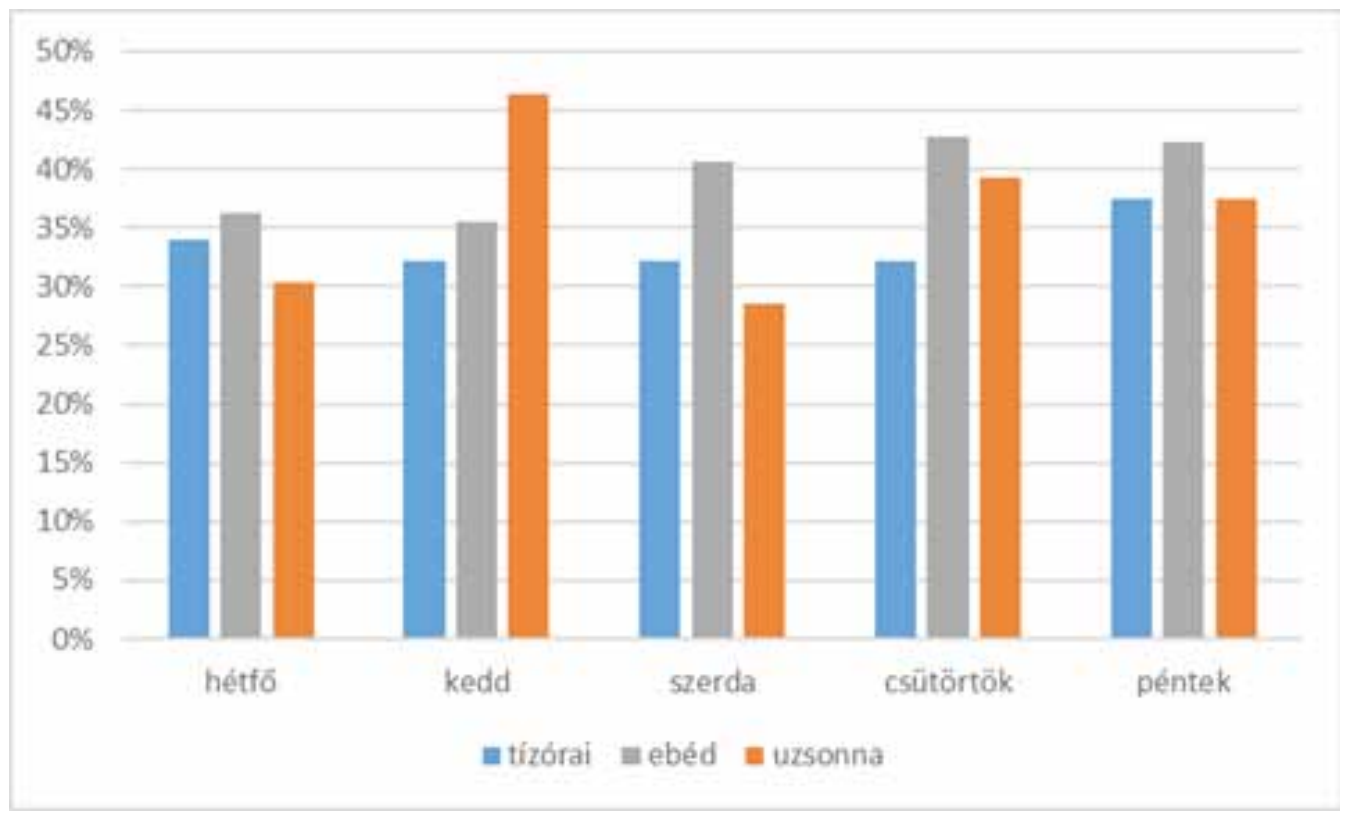

Forrás: saját szerkesztés

9. ábra: «Ízlett» válaszok aránya az ebéd egyes fogásai esetén $n_{a+k}=162$

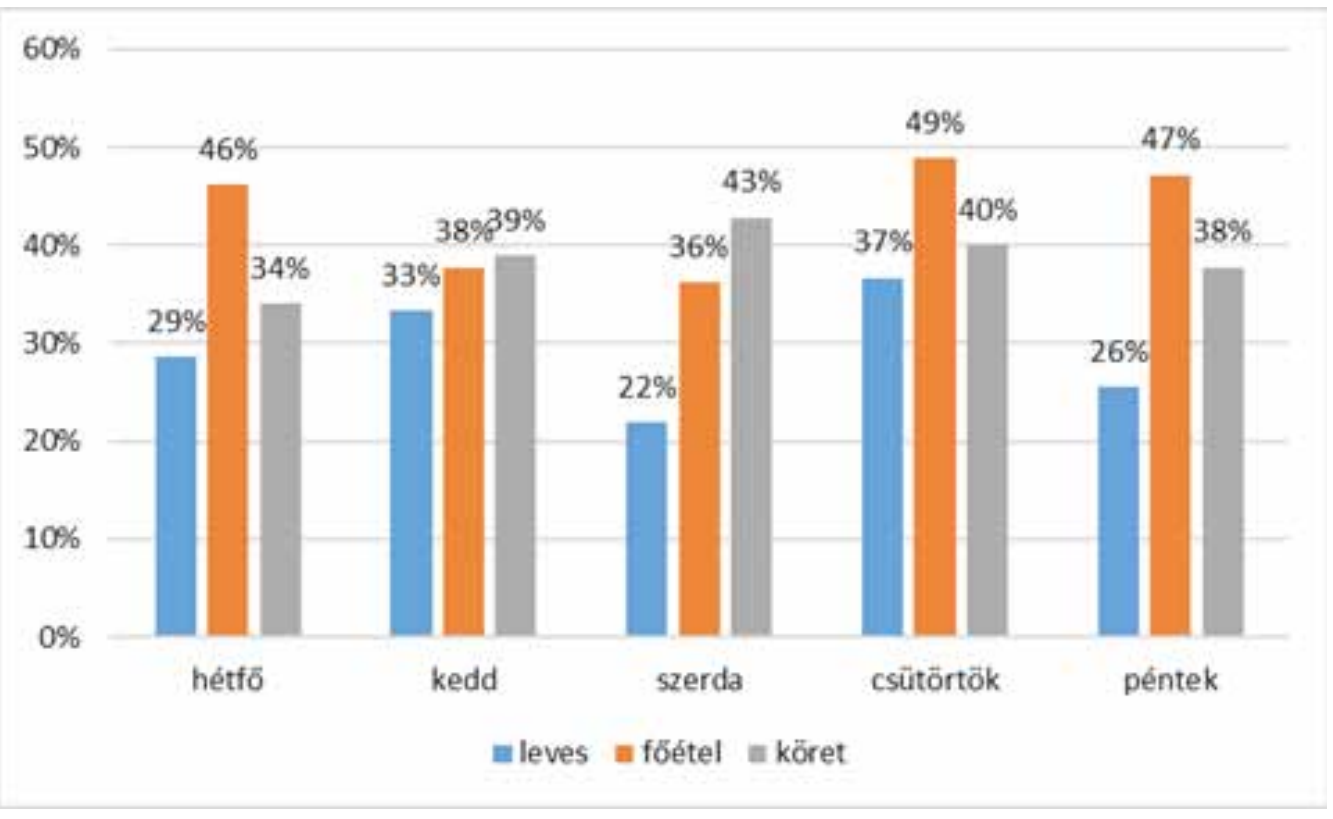

Forrás: saját szerkesztés 
Az eredmények és az étlap alapján megállapítható, hogy a kisétkezések esetében a teljes kiőrlésű termékek kapják a legrosszabb minősítést abban az esetben, ha nem a megszokott feltét került rá, míg a klasszikus péksütemények a legjobbat. A többi esetben az ízlett megjelölés kiegyenlített értéket kapott, a gyerekek valamivel több, mint 30\%-nak ízlett. Az ebédek esetében a levesek „örvendenek” a legkisebb népszerüségnek. Jelen vizsgálat során a magasabb értékelést kapott a magyaros burgonyaleves, valamint a vegyes gyümölcsleves, míg a legalacsonyabb értékelésű a kelbimbóleves, illetve a scsi leves volt.

A fóételek esetében a ragus, illetve sült húsokat tartalmazó, valamint tészta ételeket kedvelik a gyermekek, mely ebben a vizsgálatban is beigazolódott, miután kiemelt értékelést kapott a gyros csirkecomb, valamint a Budapest ragu és az ízes derelye, míg köretek esetében a klasszikus rizs, burgonya, illetve tészta köret.

A táplálkozási szokások megalapozása sok egyéb mellett a családban történik a kutatás eredményei során arra is fényt derült, hogy a családon belüli öt leggyakoribb ételtípus rangsorolva:

1. bundázott húsételek

2. pörköltek

3. sült burgonya, rizs, mint köret

4. ragus, húsos levesek

5. zöldséglevesek

Ezzel szemben a legritkábban előforduló ételek:

1. nyers zöldségsaláták

2. párolt zöldség

3. fözelékek, rakott zöldségételek

4. gyümölcslevesek

5. gyors éttermi ételek

Mindkét rangsor jól mutatja, hogy a táplálkozás területén a családi szokások beszűkültek és az étkezés egyhangúvá vált.

Az étkezések megfelelőségét, és a nem étkezők iskolai étkezésének biztosítását mutatja az iskolai büfé igénybevétele, illetve a kínálatból történő választás (10. ábra). 
10. ábra: Az iskola büfében történő vásárlások gyakorisága a közétkeztetési szolgáltatások igénybevételének függvényében $n_{\dot{a}+k}=178$

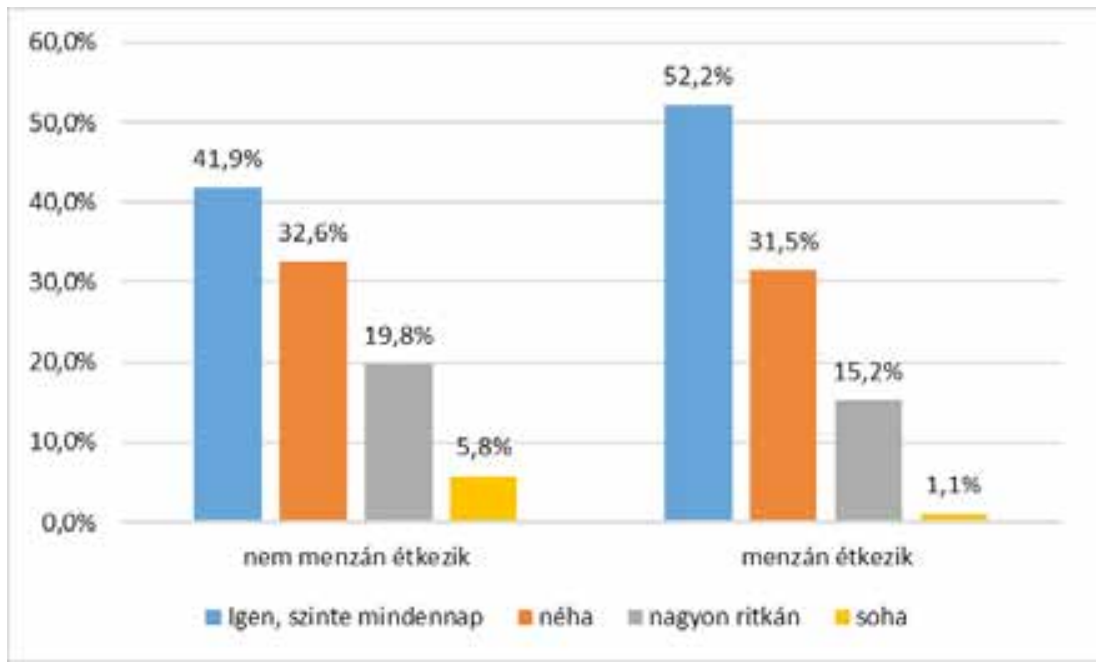

Forrás: saját szerkesztés

Statisztikailag szignifikáns eltérés a két csoport között nem mutatható ki (khí-négyzet próba $\mathrm{p}=0,213$ ), a vásárlások gyakoriságát tekintve a menzán étkezők esetében a napi vásárlás, közel $10 \%$-kal magasabb a soha pedig $4 \%$-kal alacsonyabb, mint a nem menzán étkezők esetében. A leggyakrabban vásárolt termékeket vizsgálva, azonban eltérések tapasztalhatók. (11. ábra)

11. ábra: Az iskolabüfében vásárolt leggyakoribb termékek a két csoport esetében $n_{a+k}=81, n_{a+k}=91$

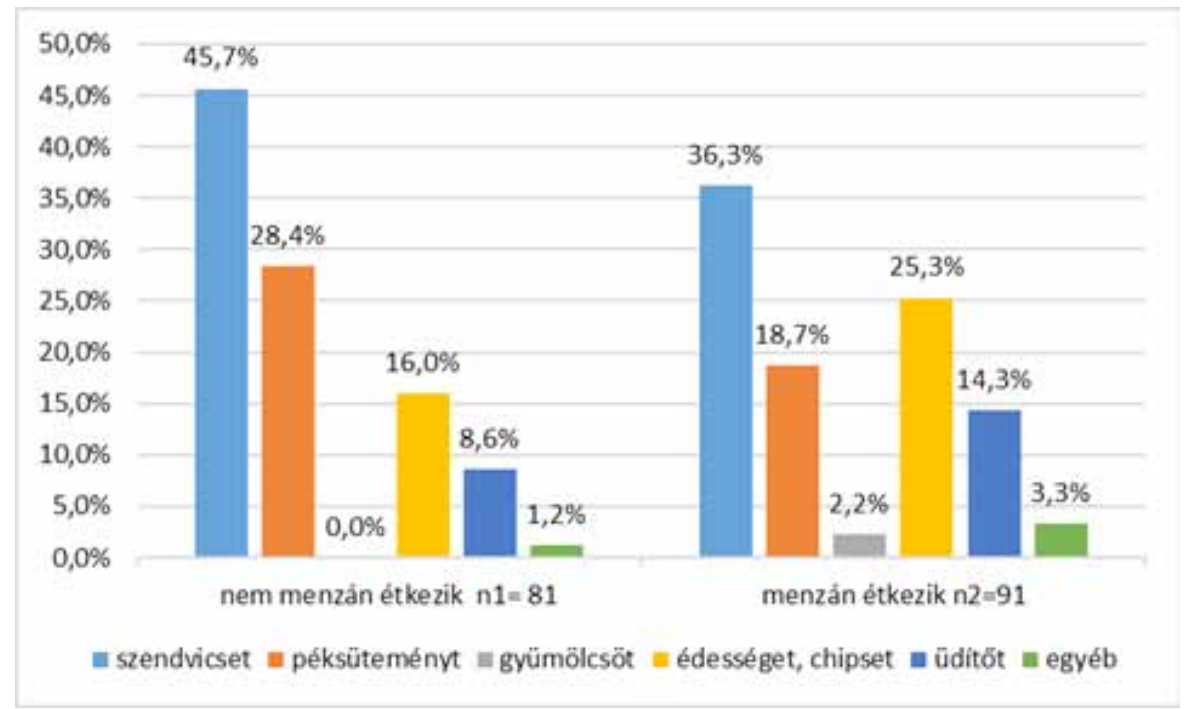

Forrás: saját szerkesztés 
Szignifikáns különbség ebben az esetben sem mutatható ki, $\mathrm{p}=0,148$. Ugyanakkor, ha az arányokat vizsgáljuk elmondható, hogy míg a menzán nem étkező gyermekek elsősorban szendvicset vagy péksüteményt vásárolnak a kieső étkezés pótlására, addig a menzán étkezőknél lényegesen nagyobb mértékben jelenik meg az édesség és az üdítő vásárlása.

\section{ÖSSZEFOGLALÁs}

A lakosság táplálkozásából, életmódjából eredendő morbiditási és mortalitási jellemzőkkel a lakosság egészségi állapota jelentős mértékben elmarad az Európai Uniós államok mutatóitól. Az életmódbeli, illetve táplálkozási szokásaink megalapozása gyermekkorunkban történik, az immáron több mint ötéves múltra visszatekintő és azt meghatározó 37/2014. (IV. 30.) EMMI rendelet a közétkeztetésre vonatkozó táplálkozás-egészségügyi előírások kapcsán vizsgáltam annak hatását és megelözési területen rejlö lehetőségeit.

A közétkeztetési szolgáltatással való elégedettség az életkor emelkedésével csökken, amely a szolgáltatás igénybevételének elhagyásával jár. Ennek következtében az étkezések változatossága is visszaesik, a meleg étel elfogyasztása helyett a gyermekek az iskolai büfében péksüteménnyel, jobb esetben szendviccsel pótolják a föétkezést.

A kutatás során megfogalmazott tényezők mindegyikével szignifikáns kapcsolatot mutat a szolgáltatás összességére adott osztályzat. Legerőteljesebb korreláció az ételek minőségével és mennyiségével kapcsolatos, ami egyben megmutatja az elörelépés lehetőségét is.

A tudatos táplálkozás kialakítása csak abban az esetben lehet hatékony, ha a gyermek ízlésének formálása érdekében mind a szolgáltató, mind a szülő hajlandó lépéseket tenni. A szolgáltató részéről fontos lenne a folyamatos elégedettség mérés és a fejlesztések kapcsán annak beépítése.

A szolgáltatók folyamatosan törekszenek arra, hogy a táplálkozási ajánlások figyelembevételével formálják a gyermek ízlésvilágát, ugyanakkor ez egyik napról a másikra nem megy, fontos, hogy egy fajta fokozatosággal álljunk a kérdéshez, legyen lehetőség a kóstolásra, új alapanyagok, új ízek megismerésére. A változás ugyanakkor a szülők nélkül elképzelhetetlen, szükség van a család nyitottságára, hogy merjenek ők is kísérletezni és egészségtudatosságukkal járjanak jó példával a gyermekek előtt.

Kapcsolattartó szerző:

Corresponding author:

Beke Szilvia

Szilvia Beke

Gál Ferenc Egyetem

Egészség- és Szociális Tudományi Kar

5700 Gyula

Szent István tér 17-19.

beke.szilvia@gfe.hu

Faculty of Health and Social Sciences,

Gál Ferenc University

Szent István square 17-19.

5700 Gyula, Hungary

beke.szilvia@gfe.hu 


\section{IRODALOMJEGYZÉK}

Bakacs, M., Kaposvári, C., Nagy , B., Varga, A., \& Zentai, A. (2018). Országos iskolai MENZA körkép 2017. Budapest: Országos Gyógyszerészeti és Élelmezés-egészségügyi Intézet. https://ogyei.gov.hu/dynamic/Orszagos-iskolai-MENZA-korkep2017-181212-2-web.pdf

Bujdosó, Z., Kerekesné Mayer, Á., \& Ujvári, K. (2012). Gasztornómia a vendéglátásban. Magyarország: Károly Róbert Főiskola. Letöltés dátuma: 2020. 01. 02., forrás: Digitális tankönyvtár web site: ttps://regi.tankonyvtar.hu/hu/tartalom/ tamop412A/2010-0010_12_Gasztronomia_a_vendeglatasban/2895/index.scorml

Caballero B (2007). „The global epidemic of obesity: An overview”. Epidemiol Rev 29, 1-5. https://doi.org/10.1093/epirev/mxm012

ELTE Pedagógiai és Pszichológiai Kar,(2020) Reflektor fényben a kamaszok egészsége és jóléte https://www.ppk.elte.hu/content/reflektorfenyben-a-kamaszok-egeszsegees-jollete.t.38869

Emberi Erőforrások minisztériuma (2014) 37/2014. (IV. 30.) EMMI rendelet a közétkeztetésre vonatkozó táplálkozás-egészségügyi elöírásokról. (2014. 04 30). Letöltés dátuma: 2020. 01. 02., forrás: Netjogtár: http://njt.hu/cgi_bin/njt_doc. cgi?docid $=169011.268149 \#$ foot 4

Greiner, E., Dánielné Rózsa, Á., \& Kovács, A. V. (2009). Országos iskolai MENZA körkép 2008. Budapest: Országos Élelmezés-és Táplálkozástudományi Intézet. Letöltés dátuma: 2019. 12 03, forrás: http://ogyei.gov.hu/dynamic/oeti_forms/menza2008. pdf

Horváth , I. (2016. 09 29). Közétkeztetés. Parlament Infojegyzet(2016). MagyarorsZág: ORSZÁGGYÜLÉS HIVATALA KÖZGYÜJTEMÉNYI ÉS KÖZMÜVELÖDÉSI IGAZGATÓSÁG KÉPVISELÖI INFORMÁCIÓS SZOLGÁLAT. Letöltés dátuma: 2020. 01 02, forrás: https://www.parlament.hu/web/guest/infojegyzet-2016

Hungast, M. (2015. 01 30). Intézményi elégedettségmérés elemzése. Magyarország. Letöltés dátuma: 2020. 01. 20, forrás: www.hungast.hu

Inchley, J., Currie, D., Jewell, J., Breda, J., \& Barnekow, V. (2017). Adolescent obesity and related behaviours: trends and inequalies in the WHO Europaen Region, 2002-2014. Copenhagen, Denmark: World Health Organization Regional Office for Europe. Letöltés dátuma: 2020. 02 18, forrás: http://www.hbsc.org/publications/international/

Kai, M. (2018). A fittség és rendszeres fizikai aktivitás szerepe az egészségnevelésbenFókuszban a NETFIT. In E. Antal, \& R. Pilling (Eds), A magyar gyermekek és fiatalok életmódja-táplálkozás, testmozgás és lélek Fehér Könyv (old.: 122-125). Budapest: TÉT Platform.

Kenesei, Z. (2017). A vevői elégedettség mérésének lehetőségei több. Statisztikai Szemle, 95(1), 29-50. https://doi.org/10.20311/stat2017.01.hu0029 
Kovács, V. A., Kaj, M., Király, A., \& Csányi, T. (2020). Mennyit mozogtak a gyermekek a koronavírus-járvány hatására bevezetett korlátozások alatt? In:E. Antal , \& R. Pilling, (Eds) A magyar lakosság életmódja járványhelyzet idején: táplálkozás, testmozgás és lélek Budapest: TÉT Platform Egyesület.

Kubányi, J., \& Szűcs, Z. (2020). Változások a karanténidőszakban a GYERE ${ }^{\circledast}$ programban részt vevő iskolás gyermekek életében. In:E. Antal , \& R. Pilling, (Eds) $A$ magyar lakosság életmódja járványhelyzet idején: táplálkozás, testmozgás és lélek Budapest: TÉT Platform Egyesület.

Molnár, S., Ács, A., Kádár, K. M., Czékmán , E., Csajbókné, É. C., \& Mák, E. (2019). Az óvodáskorú gyermekek közétkeztetésének megítélése a szülők szemszögéből. Új Diéta, 28(5), 25-28.

Schreiberné Molnár, E., Nagy-Lőrincz, Z., Nagy , B., Bakacs, M., Kis, O., Sarkadi-Nagy , E., \& Martos, É. (2017). Országos Táplálkozási ás Tápláltsági Állapot VizsgálatOTÁP 2014 A magyar lakosság vitaminbevitele. Orvosi Hetilap, 158(33), 13021313. https://doi.org/10.1556/650.2017.30832 